\title{
Health, freedom and work in rural Victoria: The impact of labour market casualisation on health and wellbeing
}

\author{
Michael McGann, Jeremy Moss and Kevin White
}

Centre for Social Justice, University of Melbourne, Melbourne, VIC; +School of Sociology, Australian National University, Canberra, ACT, Australia

\begin{abstract}
This paper presents the findings of a qualitative study of the impact of casualised and independent contractor work place arrangements on the psycho-social health of 72 workers in regional Victoria. It contributes to our understanding of the crisis in rural Australia in its use of qualitative methods focusing on the impact of work on health and well-being. There is some evidence in the literature that casualised work arrangement enhance the health and well-being of workers by giving them a sense of autonomy and freedom to negotiate their conditions of work. On the other hand, these arrangements may make an already vulnerable group even more vulnerable to uncertain work conditions, poor pay and uncertainty for their future with a significantly negative impact on their health and wellbeing. The results of these interviews support this latter perspective and show that these workers do not experience freedom and autonomy, but rather lowered social status, insecurity and serious limitations to their ability to manage their health, psychological wellbeing and social relations.
\end{abstract}

KEYwORDs: sociology; health; work; rural; Australia; psychosocial

\section{INTRODUCTION}

$\mathrm{T}$ his paper is part of a wider project on the impact of insecure work conditions on rural Victorians. We report on in-depth interviews with 72 rural workers employed under insecure contracts. MacEachen, Polzer, and Clarke (2008, p. 1020) define 'flexible work' as 'involving employment arrangements or schedules that vary from the traditional working day and week'. In this paper we adopt this definition but couch it in terms of 'insecure employment': employment that is formally unstable in the sense that work patterns may be irregular or uncertain, employment tenure limited or uncertain, and access to leave entitlements and protection against unfair dismissal restricted. In these respects, insecure employment can be contrasted with employment that is full-time and which provides access to a range of benefits and a regular work schedule (Tompa, Scott-Marshall, Dolinschi, Trevithick, \& Bhattacharyva, 2007, p. 210).

In particular, we examine the impact on the health of workers and the effects of psychosocial stressors on their ability to ensure their health and control their lives. The paper is thus a contribution to our understanding of the crisis in rural health and of the impact of changes in the labour market on people's health (Judd \& Humphrey, 2001; Leicht, Walter, Sainsaulieu, \& Davies, 2009; Ramsay, 1996; Wainer \& Chesters, 2000).

Previous studies have identified two major implications of casual/flexible/insecure employment (D’Souza, Strazdins, Lim, Broom, \& Rodgers, 2003; MacEachen et al., 2008). On the one hand the increased autonomy experienced by flexible work contracts creates a sense of control and ownership for employees. This has a significant positive impact on a person's health and wellbeing both at work and away from work. Alternatively, the flexibility is not possessed by the employee but is in fact dictated by the employer which leaves employees vulnerable and susceptible to significantly varying working hours, tasks and conditions. Positively, people who are in insecure employment may value the freedom to control the hours they work and the ability to negotiate working arrangements concerning their hours, leave and pay. Recent international studies have suggested that exercising autonomy in the workplace has a significant positive impact on people's health and wellbeing (Benz \& Frey, 2004). In particular exercising autonomy in the work force is a 
major explanatory variable in predicting people's morbidity and mortality (Marmot, 2004; Marmot, Siegrist, Theorel, \& Feeney, 1999). To the extent that insecure work allows workers more autonomy and freedom at work, it could make a major contribution to improving the health of workers in the rural sector. Negatively, insecure employment might disadvantage workers with few skills or bargaining power, impacting on their health (Artacoz, Benach, Borrell, \& Cortes, 2005).

Earlier studies have focused on urban centred skilled, technological work places such as the computer software industry (MacEachen et al., 2008), healthcare, education and managerial consulting (Leicht et al., 2009) and other skilled professions (Rubery, Ward, Grimshaw, \& Beynon, 2005). This skilled profession focus appears to be because of the rapid development in technology which allows people to work from home and the pace of competition between large multinational businesses highlights the changing nature of work. However, little research has been conducted on 'traditional' non-technological workplaces and particularly rural workplaces. This paper will review findings of other studies that have established the abovementioned results and then apply both to the rapidly developing structure of largely unskilled work in rural Victoria. We will conclude that in rural Victoria, especially with regards to non-skilled professions, the autonomy that results from the deregulation of working hours is in fact possessed solely by the employer at the expense of the employee.

\section{DEVELOPMENT OF EMPLOYMENT CONTRACT}

\section{TYPES in Australia and health CONCERNS}

Work conditions in Australia and around the world have become increasingly insecure over the past 20 years as a result of more people being engaged in 'flexible' or non-standard work (House of Representatives, 2005, p. 1; Koller, 2009, pp. 5-8; Tompa et al., 2007, p. 10; Waite \& Will, 2002). In 2009, for example, overall employment grew by $0.13 \%$. However, the number of workers in jobs with paid leave entitlements fell by $0.6 \%$. This was in contrast to the number of workers employed in jobs without paid leave entitlements - the Australian
Bureau of Statistics [ABS] (2009b) definition of casual employment - which increased by just over $80,000(+3.9 \%)$. The number of independent contractors in the workforce similarly grew by around 62,000 (+6.4\%) in 2009 (Australian Bureau of Statistics [ABS], 2009a, p. 11). Casual employment and independent contracting are now the two most prevalent forms of flexible or non-standard work in Australia, with around 20\% of the workforce (and a quarter of all employees) now engaged as casuals and just over one in ten workers now working as independent contractors (Australian Bureau of Statistics [ABS], 2009a, p. 3). Neither independent contractors nor casual employees receive any legal access to paid leave entitlements, any guarantee of ongoing work or, in most cases, any protection against unfair dismissal (Creighton \& Stewart, 2005). Many if not most are also paid on an hourly or task basis instead of on a waged salary, which makes casuals and independent contractors vulnerable to large fluctuations in their earnings, particularly if they experience illness, take time-off work, or work variable hours - the Australian Bureau of Statistics (ABS) estimates that casual employees and independent contractors are twice as likely as other workers to work in a job where the hours vary from week to week (Australian Bureau of Statistics [ABS], 2009a, p. 23; Australian Bureau of Statistics [ABS], 2009b, p. 22). Fixed-term contract employment is another significant form of non-standard and potentially insecure work in Australia, with the ABS estimating that around a quarter of a million of workers receiving paid leave entitlements in November 2009 were employed on fixed-term contract (Australian Bureau of Statistics [ABS], 2009a, p. 5). While these workers have access to paid leave entitlements and more robust protections against unfair dismissal, they nonetheless can experience high job insecurity if the duration of their contract is quite short (e.g., 3-6 months).

The rise in non-standard employment in Australia reflects the growing popularity of the 'flexible firm' model of business organisation characteristic of the new global economy (Aronsson, Gustafsson, \& Dallner, 2002, p. 152; Borland, Gregory, \& Sheehan, 2001). This model 
of business organisation is celebrated for the flexibility it gives employers to adjust to changing market circumstances so as to avoid the risk of fixed labour costs and expensive employee benefits during periods of reduced demand (Lenz, 1996, p. 556; Tompa et al., 2007, p. 211). It is also argued by proponents of flexible labour contracts that this benefits workers by allowing them to negotiate their job preferences with their employers (Lenz, 1996, p. 557). Wooden (cited in Watson, 2004, p. 3), for example, argues that 'the increased diversity in working arrangements associated with the shift away from the standard working time model has facilitated a better matching of workers' preferences to the preferences of employers'. It is claimed that flexible work, such as independent contracting, provides workers with 'more freedom to choose working hours, to decide when they take their holidays, who they work for and what type of work they undertake' (Department of Education, Employment and Workplace Relations [DEEWR], 2005, p. 8). If this is right, the proliferation of non-standard forms of employment might be a positive development for workers' health and wellbeing insofar as the exercise of control over work has consistently been shown to be beneficial for workers' physical and mental health.

The exercise of control over work in the sense of having wide decision latitude over tasks and substantial skill use and development opportunities is considered beneficial for health because it provides workers with a positive experience of their agency that buttresses their sense of selfefficacy (which, along with self-esteem, is of particular importance to health and wellbeing; see Siegrist, 2005; Siegrist \& Marmot, 2004, pp. 1465-1466). As Karasek (1979, p. 303) has argued, a work environment that allows workers to make decisions and to exercise and develop their skills can be good for workers' health because it 'represents an opportunity to exercise judgement' and so 'enhances the individual's feelings of efficacy and ability to cope with the environment.' Conversely, as Siegrist and Marmot (2004, p. 1467) argue, a work environment 'that puts high demands on working persons while providing little control over one's task performance limits the experience of self-efficacy and, thus, elicits enhanced stressful experience with adverse long-term consequences on health.' So insofar as flexible or non-standard work arrangements promote workers' control over their lives and sense of self-efficacy these may well be a positive development for workers' health and wellbeing. However, being free from the watchful eye of an employer who dictates when, where, and how a person is to work is not necessarily the same as enjoying the power of self-realisation that gives rise to the experience of self-efficacy. While, casuals and independent contractors may not be bound by any employment contract to acquiesce to the requests of clients or employers to work on particular days or during particular hours, if their work patterns are uncertain, their job security questionable, or their financial security precarious, they may struggle to realise their ambitions and life-plans or to achieve the sense that they are in control of their life (Kuhnert, 1989; McDonough, 2000). Here concerns have been identified in previous studies of non-standard work arrangements that point to a number of psychosocial health hazards.

The experience of unemployment has long been known to have severe consequences for health, especially increased risk of psychological morbidity (Ferrie, 1999, 2001). But research also indicates that the ongoing fear of losing one's job associated with prolonged experiences of job insecurity may be even more damaging to workers' health than the experience of job loss itself (Clougherty, Souza, \& Cullen, 2010, p. 115). The experience of job insecurity can elicit a sense of powerlessness and 'limi[t] the extent to which workers feel they have control over, not just their jobs, but their lives' (Scott, 2004, p. 149; also see Ferrie, 1999, p. 61). Prolonged exposure to job insecurity may undermine worker's confidence in their ability to achieve important life goals and to obtain financial and occupational security, with severe consequences for their experience of selfefficacy. For those workers least able to compete profitably in the labour market, worries about job insecurity may lead them to avoid making longterm plans and commitments that they otherwise would like to make, such as forming relationships 
and having children (Artacoz et al., 2005, p. 765). From this perspective, critics of insecure employment contracts worry that the 'flexibility' of contemporary employment practices makes workers structurally more disposed to experiencing job insecurity and periods of unemployment on a more regular basis, while the discontinuity and uncertainty that are endemic features of insecure employment contracts can engender a sense of powerless that threatens workers' sense of mastery, efficacy and esteem (Facey \& Eakin, 2010, pp. 339-340). Irregular and unpredictable work patterns may also further undermine worker's control over their lives by inhibiting their ability to balance work and family life, and by hindering their social participation (de Jonge, Bosma, \& Siegrist, 2000). For example, casual shift workers may have to live their life largely on-call because of uncertain/irregular work schedules and fears about the consequences of turning down work. 'Unpredictable work,' as Pocock, Prosser, and Bridge (2004, p. 23) explain, 'makes social participation difficult. As does low income and variable shift and finish times. If work comes up, many feel they must take it' (see also Clarke, Wayne, de Wolff, \& King, 2007, p. 321).

A further way in which insecure employment contracts may operate on workers' health is via the affect that employment as a non-standard worker may have on a person's status within the workplace (and through this, their self-esteem). Boyce, Ryan, and Imus (2007, p. 8) point out that despite some insecure workers working in high-skill occupations 'status differences are inherent in temporary work as evidenced by the lower pay, lack of pension and other benefits, and ephemeral nature of the temporary worker's employment relationship.' Such status differences may result in the marginalisation and exclusion of insecure employees by co-workers and supervisors affecting not only their self-esteem, but also their opportunities to avail of social support at work and to participate in collective decisionmaking processes and training activities. Their exclusion from training opportunities and collective decision-making processes may in turn further erode the control that workers employed under insecure employment contracts have over their employment future and occupational status (Aronsson et al., 2002, p. 156). Notably, in a previous qualitative study of casual employment in South Australia carried out by Pocock, Prosser and Bridge, casual employees frequently referred to being treated as 'only a casual' and many commented that others considered them 'less than proper workers, despite the commitment that they make to their work' (Pocock et al., 2004, pp. 14-15). Loss of self-esteem, especially among older men, and being treated with a lack of respect were key grievances for such workers.

In addition to potential threats to workers' self-efficacy and self-esteem posed by insecure work arrangements, there is also a concern that flexible and non-standard employment arrangements may have more direct and material consequences for workers' ability to manage their health. For example, as reported in a Canadian study, financial insecurities arising from irregular work patterns and the absence of any guarantee of ongoing employment can cause workers to postpone healthcare (because of the expenses involved) and to refuse to take time-off work for rest and recuperation (Clarke et al., 2007, p. 318). The ease with which they can be let go by their employer can also put pressure on insecure workers to come to work sick, to refuse to report injuries and health concerns, and to accept more hazardous tasks that permanent workers refuse to do (Facey \& Eakin, 2010, p. 335).

Any potential health effects of insecure or 'flexible' employment arrangements are of particular concern to rural and regional Victorians as it is workers in these areas who are most likely to be employed under such arrangements (Louie et al., 2006, p. 478; Productivity Commission Research Paper, 2006, p. 49). Agriculture, Forestry and Fishing, for example, is the sector of the economy with the lowest number of workers receiving paid leave entitlements and the sector with the second highest percentage of employees engaged as casuals (the proportion of workers in Agriculture, forestry and fishing engaged as independent contractors is also well above the national average (Australian Bureau of Statistics [ABS], 2009a, p. 29). Unfortunately, research on work as a social determinant of health has to date 
paid little attention to workers in regional and rural areas. This paper addresses this gap in the literature by paying particular attention to the experiences of rural and regional workers.

\section{Methods AND SAMPLe}

This paper is based on the first wave of interviews with rural and regional workers employed under insecure employment contracts, which took place at locations in and around East Gippsland, Mildura, Shepparton, Ballarat, Bendigo, Leongatha, and Hastings in late 2009. ABS data was used to identify key industries in rural and regional Victoria with a high concentration of workers employed on insecure employment contracts and interview and recruitment locations were chosen on this basis. Shepparton and Mildura, for instance, were chosen as recruitment locations because of the large proportion of workers engaged in the horticultural and foodprocessing industries in those areas (sectors that we were particularly interested in studying). In the case of Leongatha, publicly available lists of agricultural contractors indicated that this would be a good area to recruit a number of independent contractors working in the agricultural sector. The East Gippsland area was chosen because of the prevalence of fisheries workers in the area and contact with the Master Builders Association of Australia also indicated that there were a substantial number of independent contractors working in the construction industry in the area (a key sector of the economy for independent contracting). Ballarat and Bendigo were chosen so as to compare the experiences of workers in larger population centres with those in more remote areas. Research participants were recruited with the assistance of union and employee organisations in key industries of interest, while a series of advertisements were also placed in local (mostly freely-delivered) newspapers to ensure that the data sample was not limited to union affiliated workers. Prospective research participants were then screened by gender, age, industry and occupation, and employment status so as to seek a cross sample of participants. We also focused on recruiting independent contractors and casual workers, as these are by far the most prevalent types of insecure employment in Australia. However, a small number of fixed-term employees were included in the sample in order to compare how the greater protections against unfair dismissal and greater certainty of work scheduling (at least in the short-term) enjoyed by fixed-term employees relative to other nonstandard workers affected their experience.

A total of 72 research participants were recruited for the study, including 47 (65\%) casuals, 11 (15\%) independent contractors, six (8.3\%) fixed-term contract employees, and eight (11\%) permanent 'irregular' workers. This last group self-identified as casuals during the recruitment stage, although they do not strictly fall funder the ABS measure of casual employment - namely, employment without access to paid leave entitlements (Australian Bureau of Statistics [ABS], 2009b) - since they are employed under an ongoing contract and are entitled to paid leave on a pro rata basis. Nonetheless, the permanent 'irregular' workers that we interviewed all worked highly irregular and uncertain hours and their income fluctuated markedly from week to week. As one such worker told us: 'I'm classified as a permanent casual, okay. But I still have ... no control over the amount of hours ... although we are given a roster each Friday with our weekly hours on it, what tends to happen is that if we're given four hours notice, those hours can be gone for whatever reason ... If I lose those hours, I don't get paid.'

With the exception of fixed-term employees, the majority of research participants were men. The high proportion of men in casual employment in this study - 55\% - is in contrast to ABS data on casual employment, although this is explained by our particular concern with Agriculture, Forestry and Fishery workers (industries historically dominated by men). Moreover, even though more men than women worked in casual employment, women were still more likely to be employed as casuals, with casual employment representing the employment type of $68 \%$ of women in the study (compared to $63 \%$ for men; Table 1 ).

Consistent with ABS data, casual workers were more likely to be younger and less educated than other insecure workers, whereas independent 
Table 1: Characteristics of study participants

\begin{tabular}{|c|c|c|c|c|c|}
\hline & $\begin{array}{c}\text { Casual } \\
\%\end{array}$ & $\begin{array}{c}\text { Perm. Ir. } \\
\quad \%\end{array}$ & $\begin{array}{c}\text { Fix-term } \\
\%\end{array}$ & $\begin{array}{c}\text { Ind. Con. } \\
\%\end{array}$ & $\begin{array}{c}\text { Total } \\
\%\end{array}$ \\
\hline \multicolumn{6}{|l|}{ Gender } \\
\hline Male & 55.30 & 62.50 & 0 & 90.90 & 56.90 \\
\hline Female & 44.70 & 37.50 & 100.00 & 9.10 & 43.10 \\
\hline \multicolumn{6}{|l|}{ Age } \\
\hline Under 20 & 4.30 & - & - & - & 2.80 \\
\hline $20-30$ & 25.50 & 25.00 & 16.70 & - & 20.80 \\
\hline $30-40$ & 17.00 & 12.50 & 16.70 & 27.30 & 18.10 \\
\hline $40-50$ & 27.70 & 50.00 & 16.70 & 54.50 & 33.30 \\
\hline $50-60$ & 21.30 & 12.50 & 50.00 & 9.10 & 20.80 \\
\hline Over 60 & 2.10 & - & - & 9.10 & 2.80 \\
\hline \multicolumn{6}{|l|}{ Family circumstance } \\
\hline Lives with partner & 53.19 & 50 & 83.33 & 81.82 & 59.72 \\
\hline Has dependents & 40.4 & 75 & 50 & 54.5 & 47.2 \\
\hline \multicolumn{6}{|c|}{ Weekly household income } \\
\hline$<\$ 500$ & 23.50 & 8.30 & 16.70 & - & 16.70 \\
\hline$\$ 501-\$ 1000$ & 31.90 & 50.00 & 33.30 & 27.30 & 33.30 \\
\hline$\$ 1001-\$ 1800$ & 23.40 & 25.00 & 33.40 & 45.50 & 27.80 \\
\hline$>\$ 1800$ & 12.80 & 12.50 & 16.70 & 18.20 & 13.90 \\
\hline Not reported & 8.60 & 15.30 & 0.00 & 9.10 & 8.40 \\
\hline \multicolumn{6}{|l|}{ Education } \\
\hline Missing & 12.80 & 37.50 & - & - & 12.50 \\
\hline Some primary & 2.10 & - & - & - & 1.40 \\
\hline Finished primary & 2.10 & - & - & - & 1.40 \\
\hline Some secondary & 25.50 & 37.50 & - & 18.20 & 23.60 \\
\hline Finished secondary & 10.60 & - & - & - & 6.90 \\
\hline $\begin{array}{l}\text { Skilled vocational } \\
\text { course }\end{array}$ & 23.40 & 25.00 & - & 72.70 & 29.20 \\
\hline Assoc dip & 8.50 & - & - & 9.10 & 6.90 \\
\hline Undergrad dip & 2.10 & - & 50.00 & - & 5.60 \\
\hline Bachelors & 10.60 & - & 33.30 & - & 9.70 \\
\hline Postgraduate degree & 2.10 & - & 16.70 & - & 2.80 \\
\hline
\end{tabular}

permanent irregular workers mostly worked as labourers or machinery operators. As Table 3 indicates, the proportion of participants who worked in the manufacturing, construction and education sectors is broadly consistent with the distribution of the workforce across these industries as reported in the ABS 2009 Forms of Employment Survey. However, there was a substantial over representation of Agriculture, Forestry and Fishery workers, indicative of the study's focus on these workers as well as a significant under representation of workers in hospitality and retail.

The majority of interviews were held in a venue away from the interviewee's workplace, either in a room provided by the local trades hall, the interviewees' home, or a suitable café. The interviews were semi-structured and lasted for 40 minutes on average. Ethics clearance for the research was obtained from the University of Melbourne.

Following the body of research discussed above identifying the importance of control over work and social contractors tended to be older than casual and permanent irregular workers (Table 2).

Casuals were also the workers least likely to live with a partner or to have dependents. Casual and permanent irregular workers also tended to be the lowest income earners, although a significant proportion of fixed-term employees reported a weekly household income of less than $\$ 1,000$. Fixed-term employees were the workers most likely to have completed tertiary education and to work in either professional, managerial or administrator positions. By contrast, casual and efficacy and self-esteem (and through this, their health), the interview questions focused on understanding how research participants experienced the relationship between their employment contract and: (i) their ability to exercise autonomy in the workplace and control over their life; and (ii) their social participation and status within the workplace. In particular, we asked interviewees about the extent to which their employment situation elicited feelings of job insecurity and whether this had any impact on their workplace behaviours (for participation for workers' experience of self- 
TABle 2: Forms OF EMPLOYMENT OF StUdy PARTICIPANTS

\begin{tabular}{|c|c|c|c|c|c|}
\hline & $\begin{array}{c}\text { Casual } \\
\%\end{array}$ & $\begin{array}{l}\text { Perm. Ir. } \\
\quad \%\end{array}$ & $\begin{array}{c}\text { Fix-term } \\
\%\end{array}$ & $\begin{array}{l}\text { Ind. Con. } \\
\%\end{array}$ & $\begin{array}{c}\text { Total } \\
\%\end{array}$ \\
\hline \multicolumn{6}{|l|}{ Industry } \\
\hline Agriculture/fishing & 48.90 & - & - & 45.50 & 38.90 \\
\hline $\begin{array}{l}\text { Manufacturing and food } \\
\text { prod. }\end{array}$ & 10.60 & 12.50 & - & - & 8.30 \\
\hline Construction & 4.30 & - & - & 36.40 & 8.30 \\
\hline Transport and storage & 14.90 & 62.50 & - & - & 16.70 \\
\hline Telecommunications & - & - & - & 9.10 & 1.40 \\
\hline Education & 6.40 & - & 83.30 & - & 11.10 \\
\hline Finance and insurance & - & - & 16.70 & 9.10 & 2.80 \\
\hline $\begin{array}{l}\text { Property and business } \\
\text { services }\end{array}$ & 2.10 & - & - & - & 1.40 \\
\hline $\begin{array}{l}\text { Health and community } \\
\text { services }\end{array}$ & 6.40 & 25.00 & - & - & 6.90 \\
\hline $\begin{array}{l}\text { Cultural and recreational } \\
\text { services }\end{array}$ & 2.10 & - & - & - & 1.40 \\
\hline $\begin{array}{l}\text { Works in multiple } \\
\text { industries }\end{array}$ & 4.20 & - & - & - & 2.80 \\
\hline \multicolumn{6}{|l|}{ Occupation } \\
\hline Labourer & 48.90 & 12.50 & - & - & 33.30 \\
\hline $\begin{array}{l}\text { Inter. prod/transport } \\
\text { workers }\end{array}$ & 17.00 & 50.00 & & & 16.70 \\
\hline $\begin{array}{l}\text { Elem. clerical, sales, } \\
\text { service workers }\end{array}$ & 6.40 & - & - & - & 4.20 \\
\hline $\begin{array}{l}\text { Inter. clerical, sales, } \\
\text { service workers }\end{array}$ & 6.40 & - & - & - & 4.20 \\
\hline $\begin{array}{l}\text { Adv. clerical, sales, } \\
\text { service worker }\end{array}$ & 2.10 & 12.50 & - & - & 2.80 \\
\hline $\begin{array}{l}\text { Tradesperson and } \\
\text { related worker }\end{array}$ & - & - & - & 63.60 & 9.70 \\
\hline Associate professional & 10.60 & 25.00 & - & 18.20 & 12.50 \\
\hline Professional & 8.50 & - & 83.30 & - & 12.50 \\
\hline $\begin{array}{l}\text { Managers and } \\
\text { administrator }\end{array}$ & - & - & 16.70 & 18.20 & 4.20 \\
\hline Proportion of sample & 65.3 & 11.1 & 8.3 & 15.3 & 100.00 \\
\hline
\end{tabular}

attention to was their experience of work scheduling and how this affected their social participation and ability to plan their life. For example, did interviewees value flexible working hours and were they in control of their work scheduling? Did interviewees' income and working hours fluctuate from week to week and from month to month and, if so, how did this affect their social participation and control over their lives? Finally, we were interested in understanding whether interviewees had any experience of being treated unequally to permanent workers, either by coworkers or by managers, and whether this had any impact on their sense of self and their industrial citizenship (voice within the workplace and control over occupational status). For instance, were they excluded from training activities and social events at work because of their employment status?

All interviews were taped and transcribed, and a copy of the transcript was sent to interviewees for verification. The data from the

example, did they feel under pressure to come to work sick, to take unwanted shifts or to avoid taking time-off for fear of job loss or loss of shifts). We also questioned interviewees about whether the uncertain or limited tenure of their employment contract affected their ability to make medium and longer-term plans (e.g., were interviewees reluctant to enter into long-term commitments or make long-term plans while their employment future was uncertain)? Another aspect of interviewees' experience that we paid particular transcripts was cross-coded for reliability and Nvivo software was used to code and categorise the data around the central themes identified in previous studies and on the basis of new issues that emerged from the data. The data was then analysed by the researchers for common patterns emerging from the research participants' different experiences, bearing in mind the need to be sensitive to structural differences between research participants employed under different types of insecure employment contract. Attention was 
Table 3: Characteristics of non-standard workers in Australia

\begin{tabular}{|c|c|c|c|c|}
\hline & $\begin{array}{c}\text { Casuals } \\
\%\end{array}$ & $\begin{array}{c}\text { Fix-term } \\
\%\end{array}$ & $\begin{array}{l}\text { Ind. Con. } \\
\quad \%\end{array}$ & $\begin{array}{l}\text { Labour } \\
\text { force \% }\end{array}$ \\
\hline \multicolumn{5}{|l|}{ Industry } \\
\hline Agriculture, forestry \& fishing & 2.73 & 0.03 & 3.40 & 3 \\
\hline Manufacturing & 6.54 & 3.20 & 3.90 & 9 \\
\hline Construction & 5.26 & 2.50 & 32.60 & 9 \\
\hline Retail & 19.43 & 2.90 & 2.80 & 11 \\
\hline Hospitality & 20.32 & 1.90 & 0.90 & 7 \\
\hline Transport & 5.12 & 2.40 & 7.90 & 5 \\
\hline Education & 6.28 & 34.60 & 3.70 & 8 \\
\hline Health care & 9.99 & 13.90 & 5.00 & 11 \\
\hline \multicolumn{5}{|l|}{ Occupation } \\
\hline Managers & 2.82 & 10.40 & 14.10 & 13 \\
\hline Professionals & 9.72 & 47.70 & 21.80 & 22 \\
\hline $\begin{array}{l}\text { Technicians and trades } \\
\text { workers }\end{array}$ & 8.56 & 8.00 & 29.70 & 14 \\
\hline Sales workers & 20.82 & 1.80 & 3.50 & 9 \\
\hline $\begin{array}{l}\text { Machinery operators and } \\
\text { drivers }\end{array}$ & 6.54 & 1.80 & 7.40 & 6 \\
\hline Labourers & 21.92 & 3.80 & 12.10 & 11 \\
\hline \multicolumn{5}{|l|}{ Personal characteristics } \\
\hline Male & 43.00 & 43.00 & 75.00 & 54 \\
\hline Female & 57.00 & 57.00 & 25.00 & 46 \\
\hline Married or in a relationship & $42.00^{*}$ & - & 75.00 & 63 \\
\hline $15-34$ years & $57.00^{*}$ & - & 21.00 & 38 \\
\hline $35-54$ years & $31.00^{\star}$ & - & 52.00 & 45 \\
\hline $55+$ & $12.00^{\star}$ & - & 26.00 & 16 \\
\hline \multicolumn{5}{|l|}{ Tenure in job } \\
\hline In current job $<1$ year & $46.00^{*}$ & $41.00^{*}$ & 14.00 & 23 \\
\hline $\begin{array}{l}\text { Expects to be in job in } \\
12 \text { months }\end{array}$ & $79.00^{*}$ & $75.00^{*}$ & 93.00 & 90 \\
\hline
\end{tabular}

Source: ABS (2009a) except data marked with a *which is taken from ABS (2007)

also paid to analysing the data in terms of the different experiences of people who were dependent on insecure employment for their income, on the one hand, and people who did not need to rely on insecure work for their livelihood, on the other, as this was identified during the interviews as a key mediator of people's experience of insecure work. The results of the analysis of the first round of interviews are reported below. Pseudonyms have been used to protect interviewees' identities and other identifying characteristics (place of work; company name) have been removed from the interview excerpts.

\section{RESUlts OF ANALYSIS}

During the coding and analysis of the interview transcripts, three central themes emerged regarding the psychosocial health hazards of insecure employment contracts. These were: (i) the debilitating effects of uncertainty on workers' ability to plan their lives; (ii) the coercive effects of job insecurity on workers' agency in the workplace; and (iii) the marginalising effect of insecure workers' employment status and its impact on their voice within the workplace and experience of social recognition.

\section{The debilitating effects of work uncertainty}

As discussed earlier, one source of particular concern in relation to the health affects of insecure employment arrangements is the affect that the financial insecurity and uncertainty over work patterns associated with many non-standard employment arrangements potentially has on worker's ability to control their lives and to participate in social life. As Facey and Eakin (2010, p. 337) argue, 'unpredictable earnings might mean constant anxiety about meeting financial obligations' while it may also 'undermine a worker's ability to fulfil social roles (for example, as provider), which may have negative personal and social effects.' In the long-term, argue Facey and Eakin, 'income uncertainty might affect quality of life in older age because it hinders early financial or retirement planning' and 'it could also impede workers' ability to make large purchases.' A lack of regular work/reliable income may also force workers into taking whatever work they can get while it's available and it may also lead workers to work multiple jobs, creating further 
difficulties and occupational stressors. Moreover, workers with little advance knowledge of their work patterns may face tremendous obstacles to making short-term plans and commitments that could have consequences for their work-life balance and also their social participation. Many of the workers interviewed, particularly - but not exclusively - casual and permanent irregular workers, registered these concerns:

Sometimes I work one day a week, sometimes four days a week, sometimes it's nearly full-time for about 3 months ... You cannot predict it ... It's hard to organise your days; you don't know what you're doing from one day to the next. You don't know whether you're going to work next week, kind of thing, you can't make appointments. (Susan, casual production worker, Shepparton)

You're on call 7 days a week from anything from 7 in the morning to 7 or 8 at night ... you can't plan a week ahead and say, "Oh yeah, next weekend we'll ... or I'll do something," because you don't know if you're going to miss out on work or not. You know, you can plan to do it, but come time, come the weekend or whatever it is, well, you've got to decide, "Do I go or do I stay and work?" You might pick up 20 hours on a weekend. It's busy, it's very busy, so if you don't work, you miss out and you don't get paid, yeah. So it doesn't worry me I suppose, but it does and it doesn't. Work-wise, it doesn't worry me; missing out on the family life or functions or whatever, yeah, I miss out on them sometimes. (Daniel, casual fisheries worker)

Irregular work patterns also caused frequent fluctuations in workers' earnings, often putting them in financially precarious circumstances and contributing to a more stressful home environment because of difficulties in providing for household needs. As one casual teacher in East Gippsland who every year was laid off for the summer holidays commented of the consequences of the downturn in earnings she was facing: 'I end up getting incredibly broke, very depressed, borrow money left right and centre to pay the mortgage, to pay the power, to buy food and then spend first term paying it all back ... I'm not suicidal but I feel like it sometimes though, I do. I've actually got bald patches all over my head from just yeah, anxiety ... "How can I make ends meet, will we get below this summer, how can I buy presents for my children?",

A number of people interviewed, including independent contractors and fixed-term employees, were forced to forgo taking time-off work and had to postpone plans - even putting off health care - because they felt they couldn't afford to take time-off work or to spend savings while their employment future was uncertain:

I had to have a sinus operation and that meant I would have been off work for about four weeks. I had to wait until I went permanent part time; I haven't had the operation but I was waiting until I went permanent part-time. (Yvonne, Aged Care Worker/ex-casual)

Two years ago, took a week off. So I don't have any days off ... It's that tight at the moment that you can't afford to take a day off. (Hugh, telecommunications sub-contractor)

For me, all we can take as given is that at the moment I have no contract at the end of December ... So at the moment we've got things we wanna do around the house ... I'd like to get the fences done out in the paddock so I can get a cow but I also have to turn around and go "Well that \$2000, I might need that come Christmas." (Katherine, project manager/fixed-term employee)

The need to take whatever work is available and the financial insecurity created by irregular and uncertain work scheduling - coupled with lack of paid leave entitlements - was motivating many workers to come to work sick or injured (though this was not an issue for fixed-term employees):

Well in the past as a casual, you basically have to be shitting in your pants not to go into work really. Because this work, the money, you wouldn't give a shit if you were sick, you'd still go in [Interviewer: So you've done 
that a few times?] Oh yeah, definitely. You can't afford not to ... At the end of the day, when you're a casual, you've got to do the job. If you don't, you don't get paid. Simple as that. (Adam, crane operator)

You need money, it doesn't matter how sick you are ... you know, they don't care because if you want to stay home of course they say come in or nothing and that's the time I get really sick and I push myself to the edge and there's a time that I fainted. I remember one time I fainted at a block because the heat was too much, the heat was too much but I pushed it, because I need more boxes, because the price is not the much you know. I'm lucky to get $\$ 500, \$ 400$ [per week] you know, and if I don't push myself what can you do with $\$ 100$ a week? (Nicola, Fruit-picker)

Certainly there were a number of workers who felt that their employment arrangement gave them more flexibility and control over their work so that they could better balance work and family life and take time-off as desired. Independent contractors, in particular, spoke of the benefit of 'being their own boss'. 'What work you do is yours,' as Trevor, an agricultural contractor in Leongatha explained. 'It's not as if you are working for someone - we control what we do.' 'As long as you make sure you get enough work done every day, you pretty much make your own hours,' explained Mark, a carpenter and sub-contractor in East Gippsland. 'And if I want to have a day off, I just have a day off ... that's the benefit of working for yourself; you make that decision. (Mark, Carpenter/ Independent Contractor, East Gippsland)

But whether people genuinely enjoyed such flexibility and control over their work scheduling depended very much on whether they were reliant on the income from their employment and on whether they were confident that there would still be plenty of work available if they took time-off. As one casual with young children who highly valued the flexibility that her work gave her put it: 'I think if you're going to temp you need to make sure you've got a permanent income coming in from somewhere else. What sort, I don't know but there needs to be, otherwise you would get really stressed.' Fruit-pickers who had in the past cherished the flexibility of their working hours were now unable to get enough work to survive and many were reluctant to turn down any work that was available, even if they felt sick or injured. Similarly, while a number of independent contractors valued the control that being self-employed gave them, others who relied on a single client for all their work (dependent contractors) did not feel as though they had as much control over their work. As Hugh, a telecommunications sub-contractor explained, 'they don't employ people, this mob. So they just get you contracting and that standard has definitely deteriorated every year since I've started ... They just give you whatever they want. You have no control.' Tom, a building sub-contractor in East Gippsland likewise explained: 'you are still working for somebody else anyway really. At the end of the day, you are your own boss, if you want to go home, you are going home, but there is no guarantee he is going to tell you to come back the next day.' Tom went on to say that he would prefer to be directly employed rather than hired as an independent contractor: 'you're basically a business, not that you want to be; you just want to get up, go to work every day and come home like everybody else. But because of who you are, you're forced into being a small business.' Tom's experience suggests that the reason why some people go into independent contracting may have less to do with the value they place on being self-employed and far more to do with the fact that they cannot find work in their industry under any other terms of employment.

\section{The coercive effects of job insecurity}

One of principal criticisms of insecure employment contracts is that the lack of protection against unfair dismissal and the financial precariousness of their employment situation makes flexible workers particularly vulnerable to exploitation within the workplace in the sense that fears for their job security may motivate insecure workers to take on more dangerous work, to come to work sick, and to refuse to report workplace injuries and occupational health and safety incidents 
(Macdonald \& Holm, 2002). The data gathered certainly supports this criticism, although permanent irregular workers, fixed-term employees and independent contractors to a lesser extent, appear to be less vulnerable to these psychosocial work hazards than casual workers (Benach \& Muntaner, 2007; Benach, Muntaber, \& Santan, 2007). Causal workers are acutely aware of the precariousness of their employment tenure and find themselves affected by the experience of job insecurity on a daily basis:

For me, job security is everything. I'm bringing up four kids, I've got a mortgage and I'm running two cars. So you need security. Everybody does, you know? So that's a scary thing for me ... It probably doesn't affect my work but it affects the way I think about work and think about how to approach things ... I still do my work. But if I've got the two-way in my hand, I've got to be careful what I say to who. So it affects the way I think. (Patrick, Construction labourer, Shepparton)

The comparative ease with which they could be let go and the need to maintain a positive impression with their employer put pressure on a number of workers to refuse to speak out about injuries and concerns and to accept work that permanent employees would refuse.

[B]eing a casual person you can't really complain or ask too many questions because they simply won't hire you anymore ... I've definitely bitten my tongue on many occasions, thinking, "I just can't go there. I can't mention this or it will jeopardise any future work, so I'll just keep quiet and say nothing," which has been pretty hard to bear at times. (Trish, casual teacher, East Gippsland)

Anything that the permanents don't want to do, they refuse, they don't do it and they say, "That's the reason why we've got the casuals here, that's their job, we don't have to do shit jobs like that," they have said. And we have to do it ... If you say, "No", you're out of there. And everyone who's a casual, who's a seasonal temp, you know that. If you refuse work, you're out the door ... So it's not a fair place at all to work, it really isn't. And they know that we're desperate for work and like you're there, you're day to day, you don't know which day they're going hook up to say, "Right, you're out of here." So yeah, you behave. (Angela, food production labourer, Shepparton)

Fruit pickers reported feeling exploited by contractors and having to take whatever pay contractors decided to give them because of the scarcity of work and the risk of being put off if they complained:

[T] he contractors, they're picky because they know people want job; they get very picky, you know. They might accept you this [time] but you know, if they give you less money, sometimes you don't get paid, you go 'look we need the money for, because we've got bills, we've got shopping.' And if you go, you know, complaining to them, they'll sack you. (Nicola, casual fruit picker, Midlura)

What was particularly surprising (and unexpected) was that a number of fixed-term employees appeared to be similarly affected by the experience of job insecurity despite the greater protection that they received against unfair dismissal:

I've only got 3 months left on my contract so do I try and play nice for the next 3 months to keep a contract or do I continue to do my job? We've had many discussions based on [Jonathan] saying "Just shut up and play nice, go to work, get paid and come home again 'cause you're only on a contract." But having to actually rectify that within yourself and turn around and say "Am I comfortable going to work just to collect a pay check but not doing what I see as being ... productive," yeah. You know, productive is that I have to rub some people up the wrong way but that's part of the job so that's a real catch 22 for me and I don't like to think that I'm going to play that game. (Katherine, project manager/fixed-term employee)

\section{Marginalising effects of non-standard employment status}

As we noted earlier, besides the effects of financial insecurity and irregular and uncertain work 
scheduling on workers' control over their lives, one of the pathways through which insecure employment arrangements may adversely affect the health of workers is via any status inequalities that are associated with being engaged under an insecure employment contract. For instance, if insecure workers are excluded from full participation in meetings, training activities, and social functions at work, this can deprive such workers of access to networks of social support and inclusion at work that are important for maintaining psychological wellbeing (Berkman \& Syme, 1979). Indeed, insecure workers may suffer reduced access to social support at work merely as a result of the irregular and intermittent scheduling of work. That is, the irregular and intermittent nature of their work patterns may leave insecure workers with fewer opportunities to develop meaningful relationships with colleagues. This was something that a number of the independent contractors interviewed commented upon, many of who worked alone and therefore rarely had contact with colleagues. 'It's very isolated,' as a claims investigator in regional Victoria explained. 'There's companies that I've never actually been to ... We talk on the phone constantly but never met them face to face, or interacted, or socialised with them.' 'I suppose where I actually feel it is at Christmas,' as she went on to explain, 'because I'm hooning around all these places, they're organising all their Christmas do's.' A number of casuals similarly complained that the irregular and uncertain nature of their work can make it more difficult for them to participate in social networks at work. As a food production worker in Shepparton explained, 'like if they have a morning tea, you have to sort of pre-order what you want. Well, the casuals can't do it because they don't know if they're going to be there on that day ... the casuals can't participate because we don't know if we're going to be there on the day. So that excludes us'.

However, as critics of insecure employment contracts have pointed out, insecure workers may not only face obstacles accessing social support and participating in meetings, social functions, and training activities because of working irregular and intermittent schedules; they may in fact be actively marginalised by permanent co-workers and supervisors if they are perceived as having lower status (Lewchuk, de Wolff, King, \& Polanyi, 2005; Tompa et al., 2007, p. 218). The issue here is not simply that insecure workers will find their opportunities for social participation at work comparatively diminished but that, as a consequence of their employment status, they will find their status as free and equals actively denied. For example, if workers engaged under insecure employment contracts feel treated as less then equal workers, be it because of the way that permanent co-workers and managers relate to them or because of their exclusion from workplace decision-making processes, training activities, and social functions because they are not ongoing workers, this may provoke feelings of anger and frustration and a loss of self-esteem. This is a worrying aspect of insecure employment arrangements not only because it may be highly destructive of workers' self-esteem, but also because, as Aronsson et al. (2002, p. 172) have pointed out, being excluded from meetings and training activities can also severely restrict workers' control over their employment future and occupational status (i.e., more limited training opportunities hindering career progression and exclusion from meetings hindering workers' ability to highlight their concerns to management). Missing out on training and meetings may furthermore directly increase insecure workers' physical exposure to the risk of incurring a work-related injury or illness if they are not provided with the knowledge and skills they need to safely perform their job.

On the basis of the first wave of interviews, the marginalising effects of non-standard employment status appear to be of most concern to casual workers, with a number of casuals reporting that they felt treated like second-class workers by management as well as some colleagues.

'I sort of sense being a casual ... you don't get involved in any decisions or anything like that, so I suppose you do feel a bit at arms length to the place ... And I think if you talk 
to any other casuals, I think they'd say the same thing, yeah. Sometimes, I suppose, you get the feeling they're only using you, which they probably are, because once you've finished the work, that's it, you go home, you don't get paid or anything, so that's it. You're just there to do the work that's there for whatever hours it is and then you go home. [Interviewer: As a casual, do you get the sense that you're a second class worker?] Yeah, I suppose. And no one would ever say that I suppose, but you do get that feeling'. (Daniel, fishery worker)

'You did almost feel a bit second-class at times,' reported Simon, a dockworker who had worked as a casual for more than a decade before being made permanent just before the interview: “'You're just a casual," you know what I mean?' One fruit picker in Mildura, Nicola, went so far as to say that she felt treated 'like a slave or something ... you're just a nothing, you have no value.' While other fruit pickers did not go quite so far in describing their treatment by their employers as slave-like, the sense of being treated like they were 'just pickers' was a common one:

Bill: 'Yeah but this mob's got this place they come out with this big sprayer ... the oranges are here and the row's right there ... They come up and say, "Oh shift your car, your car's in the road we gotta spray". Michael: 'They don't care ... 'cause at the end of the day we're just pickers. There's a lot of that.' Toni: 'Mmmm, and that's how we get treated all the time'. (fruit pickers, Mildura)

With some exceptions, casuals were being excluded from events and activities because they were not seen as 'real' members of the workplace community. Julia, a sessional teacher at a TAFE in Northern Victoria, spoke of the difference between how the casuals and the real workers were treated by management: 'they definitely make a distinction between the things that they will invite all the sessionals to and the casuals to, and the things that they will invite the real workers to.' Her exclusion from meetings at work on the basis of her employment status was having a particularly debilitating affect on Trish, a school teacher in East Gipplsand: 'If they have a meeting they'll hire me to fill in for the teacher so they can all go off to a meeting but I'm left out ... They had a meeting today, I wasn't invited. I'm just a nobody basically, and it does terrible things to your self-esteem I can tell you. I do painting on the side, that's my therapy. If I didn't do that I think I would have been locked up a long time ago because it just squashes your self-esteem.' Trish pointed out that her exclusion from meetings was not only eroding her self-esteem; it was also hindering her ability to contribute positively to the workplace community and to influence learning outcomes: 'The thing I find incredibly irritating is that I have no say ... I can see obvious ways to improve outcomes, the teaching-learning outcomes but nobody's listening to me.'

Some casuals reported that permanent coworkers would even treat them with outright hostility:

The full time workers give the casuals a hard time ... Just say things and be nasty and give them looks. Make you feel uncomfortable if they can, have a bit of a whinge, bitch. (Ruby, labourer, packing sheds, Shepparton)

[I]t's the permanent women that are the problem. They bully us, intimidate us, just treat us like, I actually believe they're threatened by us, that they think we're going to take their jobs. I don't know. I don't know what the problem is, I don't know why they're the way they are. It's just that some of them have been there for like 20 odd years and they think they own the place [laughs] but why they are the way they are to us, they just treat us really bad. (Susan, labourer, packing sheds, Shepparton)

An integration aide worker at a TAFE commented that, as a result of the increasing casualisation of her workplace, she felt that there was 'a much more competitive feeling and a much more stressful feeling than there used to be'. As she explained, "the permanents might feel, "my job can go casual." ... I have definitely felt that 
coming from people, that, "Oh God, they're putting on a casual. What do they think, my work can be done in, only a certain amount of time and that you don't have to have any real knowledge",

The fear that they will lose their jobs, or that their jobs will be casualised, can motivate permanent workers to try to undermine the status of casuals within the workplace by withholding support from them and by excluding them from co-worker networks, although the extent to which casual workers are susceptible to marginalisation will likely depend on how permanent workers perceive the use of flexible workers by their employer (Boyce et al., 2007, p. 11). There was some evidence of this taking place in the workplaces where casual interviewees worked:

They [permanent co-workers] never want you to know anything about the machines, they won't let you do any of it because they don't want you to know, which I guess comes from them being threatened by us. I don't know. We're not allowed to know how the machines work in case we know too much. (Susan, labourer, packing sheds, Shepparton)

\section{Conclusion}

As Karasek and Theorell (1990) point out, the health of the individual worker does not necessarily have to be physically at risk for the impact of work relations to make themselves felt. Lack of autonomy at work, lack of control over the production process and separation from fellow workers - the key components to Marx's account of alienation - are all contributors to illness and disease and are the burden of social inequality and its impact on health (Bell et al., 2004). On this basis, and from our interviews, it is clear that non-standard employment arrangements - and casual employment contracts in particular - do indeed precipitate psychosocial health hazards.

There is strong evidence to suggest that the work uncertainty of their employment arrangement is having a debilitating affect on the ability of casuals and permanent irregular workers in particular to control and plan their lives. Although fixed-term employees and independent contractors appear to be less affected by work uncertainty in the immediate term, there is nevertheless evidence of fixed-term employees and independent contractors postponing future plans and holidays and delaying health care because of doubts over their income and job security. Similarly, there is evidence that concerns for their job security are inhibiting the agency and voice of fixed-term employees within the workplace and leading dependent contractors to come to work sick and to refuse to take time-off; although, again the evidence from the first round of interviews points to the particularly coercive effects of job insecurity on the agency and voice of casuals. There is also strong evidence to suggest that casual employees in particular enjoy reduced opportunities to access social support at work and to participate in decision-making processes at work because of their non-standard employment status and how this is perceived by co-workers. While other non-standard workers' are not discriminated against because of their employment status in the way that casuals are, they nevertheless may have reduced opportunities to access social support at work because of either irregular work patterns or more limited durations of employment within the same workplace.

Important consequences follow for the formulation of public policy in Australia, particularly in relation to the health of low-income and lowerskilled workers - the workers most likely to be employed under casual employment contracts and rural and regional communities. Insofar as insecure employment contracts are a danger to workers' health, efforts to improve the health of low-income groups and of rural and regional communities cannot concentrate on the provision of improved health care alone but must instead attend also to the structuring of employment arrangements and the quality of work opportunities. As the report of the WHO Commission on Social Determinants of Health $(2008$, p. 8$)$ on the Social Determinants of Health stresses, "[a]chieving health equity requires safe, secure, and fairly paid work, year-round work opportunities, and a healthy work-life balance for all. Consequently, if the health of people living in rural and regional areas is to be improved, careful decisions will 
have to be made about the allocation of resources. Trade-offs may need to be made between directing resources towards the provision of improved and expanded health care services - the preferred strategy of the National Health and Hospital Reform Commission (2009, Chapter 3) - and targeting resources towards the provision of wider work opportunities, more stable employment arrangements and better psychosocial work environments. Policy development in areas historically outside the purview of health policy labour relations and economic policy - will also need to take account of the impact of any policy changes on population health. These policy areas can no longer be treated as distinct spheres that can be quarantined off from wider debates. Instead, the spill over effects of any policy changes on the social determinants of health will need to be considered and the results of these considerations included in analyses and evaluations. This is all the more so when we consider that particular non-standard employment arrangements notably casual employment - may represent a threat not just to the individual workers who wind up in those employment arrangements but to the health of all Australians.

Notwithstanding the seriousness of the concerns raised by interviewees, it is important to bear in mind that these are only interim findings and warrant much further analysis and investigation before any conclusive judgments can be made about the health effects of non-standard employment arrangements. In particular it will be important to pay closer attention to the way that differences in workers' occupational class, household situation and industry of employment mediate their respective experiences of job and financial insecurity and of uncertain work patterns. In this respect, while this paper did not go into the issue, the fishermen interviewed appeared to be far less perturbed by their lack of protection against unfair dismissal and uncertain work patterns than other casuals despite their work patterns being similarly irregular and unpredictable. One explanation for why this may be so is that fishermen appeared to be more confident of remaining financially secure than other workers during periods of no work and they also appeared to accept work uncertainty as part and parcel of their chosen way of life. This suggests that the expectations people bring to their employment arrangement may be key in determining the degree to which they are distressed by any insecurity and uncertainty associated with it. It will be important to more closely consider the differing experiences of fishermen and other casuals as doing so may point to factors that can alleviate some of the hazards posed by irregular and uncertain work patterns. It will also be important to consider whether the debilitating effects of work uncertainty, the coercive effects of job insecurity, and the marginalising effects of non-standard employment status are of equal concern to workers across different industries. For instance, are casuals in the agricultural sector (e.g., fruit pickers) as affected by attributions of lower employment status as casuals in (say) manufacturing, production, and education given that they may have less interaction with permanent workers and may be less concerned about participating in decisionmaking at work or availing of professional development and training opportunities? Follow up interviews over the next year will hopefully help to shed light on some of these issues as well as enabling the study to further mine the experiences of participants in relation to the ongoing affects of work uncertainty and job insecurity on their health, wellbeing and quality of life.

\section{Acknowledgement}

This research was funded by an ARC Linkage Grant in collaboration with VicHealth.

\section{References}

Aronsson, G., Gustafsson, K., \& Dallner, M. (2002). Work environment and health in different types of temporary jobs. European Journal of Work and Organizational Psychology, 11(2), 151-175.

Artacoz, L., Benach, J., Borrell, C., \& Cortes, I. (2005). Social inequalities in the impact of flexible employment on different domains of psychosocial health. Journal of Epidemiology and Community Health, 59, 761-767.

Australian Bureau of Statistics. [ABS]. (2007). Forms of employment 6359.0 November 2007. Canberra, ACT, Australia: Author.

Australian Bureau of Statistics. [ABS]. (2009a). Forms of employment 6359.0, November 2009. Canberra, ACT, Australia: Author. 
Australian Bureau of Statistics. [ABS]. (2009b). 'Casual employees', Australian social trends 4102.0, June 2009. Canberra, ACT, Australia: Author.

Bell, R., et al. (2004). J. Ferrie (Ed.), Work, stress, health:The Whitehall II study. London, England: International Centre for Health and Society, University College London.

Benach, J., \& Muntaner, C. (2007). Precarious employment and health: Developing a research agenda. Journal of Epidemiology and Community Health, 61, 276-277.

Benach, J., Muntaner, C., \& Santana, V. (2007). Employment conditions and health inequalities: Final report to the WHO commission on social determinants of health (Csdh). Employment Conditions Knowledge Network (EMCONET).

Benz, M., \& Frey, B. (2004). Being independent raises happiness at work. Swedish Economic Policy Review, $11,95-134$.

Berkman, L. F., \& Syme, S. L. (1979). Social networks, host resistance and mortality: A nine year follow-up study of Alameda County residents. American Journal of Epidemiology, 109, 186-203.

Borland, J., Gregory, B., \& Sheehan, P. (2001). Inequality and economic change. In J. Borland, B. Gregory, \& P. Sheehan (Eds.), Work rich, work poor: Inequality and economic change in Australia (pp. 1-20). Melbourne, VIC, Australia: Centre for Strategic Economic Studies, Victoria University.

Boyce, A., Ryan, A. M., \& Imus, A. (2007). Temporary worker, permanent loser? A model of the stigmatization of temporary workers. Journal of Management, 33(1), 5-29.

Clarke, M., Wayne L., de Wolff, A., \& King, A. (2007). This just isn't sustainable: Precarious employment, stress and workers' health. International Journal of Law and Psychiatry, 30, 311-326.

Clougherty, J. E., Souza, K., \& Cullen, M. (2010). Work and its role in shaping the social gradient in health. Annals of the New York Academy of Sciences, 1186, 102-124.

Creighton, B., \& Stewart, A. (2005). Labour Law (4th ed.). Sydney, NSW, Australia: Federation Press.

de Jonge, J., Bosma, R., \& Siegrist, J. (2000). Strain, effort-reward imbalance and employee well-being: A large scale cross-sectional study. Social Science and Medicine, 50, 1317-1327.

Department of Education, Employment and Workplace Relations [DEEWR]. (2005). Discussion paper: Proposals for legislative reforms in independent contracting and labour hire arrangements. Canberra, ACT, Australia: Author.

D'Souza, R. M., Strazdins, L., Lim, L.-Y., Broom, D., \& Rodgers, B. (2003). Work and health in a contemporary society: Demands, control, and insecurity. Journal of Epidemiology Community Health, 57, 849-854.

Facey, M., \& Eakin, J. (2010). Contingent work and ill-health: Conceptualising the links. Social Theory \& Health, 8, 326-349.

Ferrie, J. (1999). Health consequences of job insecurity In J. Ferrie, M. Marmot, J. Griffiths, \& E. Ziglio (Eds.) Labour market changes and job insecurity: A challenge for social welfare and health promotion (European series no. 81). Geneva, Switzerland: WHO Regional Publications.

Ferrie, J. (2001). Is job insecurity harmful to health? Journal of the Royal Society of Medicine, 94, 71-75.

House of Representatives. (2005). Making it work: Inquiry into independent contracting and labour hire arrangements. Canberra, ACT, Australia: Standing Committee on Employment Workplace Relations and Workforce Participation, Parliament of Australia.

Judd, F., \& Humphrey, J. (2001). Mental health issues for rural and remote Australia. Australian Journal of Rural Health, 9, 254-258.

Karasek, R. (1979). Job demands, job decision latitude, and mental strain: Implications for job redesign. Administrative Science Quarterly, 24, 285-308.

Karasek, R., \& Theorell, T. (1990). Healthy work: Stress, productivity and the reconstruction of working life. New York, NY: Basic Books.

Kivimaki, M., Vahtera, J., Elovainio, M., Virtanen, M., \& Siegrist, J. (2007). Effort-reward imbalance, procedural injustice and relational injustice as psychosocial predictors of health: Complementary or redundant models? Occupational and Environmental Medicine, 64, 659-665.

Kivimaki, M., Vahtera, J., Virtanen, M., Elovainio, M., Pentti, J., \& Ferrie, J. E. (2005). Temporary employment and risk of overall and cause-specific mortality. American Journal of Epidemiology, 158, 663-668.

Koller, P. (2009). Work and social justice. Analyse E Kritik, 31, 5-8.

Kuhnert, K. (1989). The relationship between job insecurity and employee health. Group and Organisation Studies, 14, 399-410.

Leicht, K., Walter, T., Sainsaulieu, I., \& Davies, S. (2009). New public management across nations and contexts. Current Sociology, 57(4), 581-605.

Lenz, E. A. (1996). Flexible employment: Positive work strategies for the 21st century. Journal of Labor Research, 17(4), 555-566.

Lewchuk, W., de Wolff, A., King, A., \& Polanyi, M. (2005). Beyond job strain: Employment strain and the health effects of precarious employment. In Work in a 
global society working paper series. Hamilton, ON, Canada: Labour Studies Programme, McMaster University. Louie, A. M., Ostry, A. S., Quinlan, M., Keegel, T., Shoveller, J., \& LaMontagne, A. D. (2006). Empirical study of employment arrangements and precariousness in Australia. Relations Industrielles, 61(3), 465-489.

Lynch, J., Kaplan, G. A., Pamuk, E. R., Cohen, E. R., Heck, K. E., Balfour, J. L., et al. (1998). Income inequality and mortality in metropolitan areas of the United States. American Journal of Public Health, 88, 1074-1080.

Macdonald, F., \& Holm, S. (2002). Precarious work, uncertain futures. Changing pressures (Brotherhood of St Laurence 10), March, 1-8. Brotherhood of St Laurence.

MacEachen, E., Polzer, J., \& Clarke, J. (2008). 'You are free to set your own hours': Governing worker productivity and health through flexibility and resilience. Social Science and Medicine, 66(5), 1019-1033.

Marmot, M. (2004). The status syndrome. London, England: Bloomsbury.

Marmot, M., Siegrist, J., Theorel, T., \& Feeney, A. (1999). Health and the psychosocial environment at work. In M. Marmot \& R. Wilkinson (Eds.) Social determinants of health. New York, NY: Oxford University Press.

Marmot, M. G., Bosma, H., Hemingway, H., Brunner, E., \& Stansfeld, S. (1997). Contribution of job control and other risk factors to social variations in coronary heart disease incidence. The Lancet, 350, 235-239.

McDonough, P. (2000). Job insecurity and health. International Journal of Health Services, 30, 453-476.

Pocock, B., Prosser, R., \& Bridge, K. (2004). Summary of main report: 'Only a Casual ...' Adelaide, SA, Australia: Labour Studies, School of Social Sciences, University of Adelaide.

Productivity Commission Research Paper. (2006). The role of non-traditional work in the Australian labour market. Canberra, ACT, Australia: Australian Government Productivity Commission.

Ramsay, J. (1996). The national mental health strategy. Australian Journal of Rural Health, 4, 53-56.

Rubery, J., Ward, K., Grimshaw, D., \& Benyon, H.

(2005). Working time, industrial relations and the employment relationship. Time and Society, 14, 89-111.

Scott, H. (2004). Reconceptualising the nature and health consequences of work-related insecurity for the new economy: The decline of workers' power in the flexibility regime. International Journal of Health Services, 34(1), 143-153.

Siegrist, J. (1996). Adverse health effects of high effort/ low reward conditions. Journal of Occupational Health Psychology, 1, 27-41.

Siegrist, J. (2005). Social reciprocity and health: New scientific evidence and policy implications. Psychoneuroendocrinology, 30, 1033-1038.

Siegrist, J., \& Marmot, M. (2004). Health inequalities and the psychosocial environment - Two scientific challenges. Social Science and Medicine, 58, 1463-1473.

Tompa, E., Scott-Marshall, H., Dolinschi, R., Trevithick, S., \& Bhattacharyya, S. (2007). Precarious employment experiences and their health consequences: Towards a theoretical framework. Work, 28, 207-224.

Wainer, J., \& Chesters, J. (2000). Rural mental health: Neither romanticism or despair. Australian Journal of Rural Health, 8, 141-147.

Waite, M., \& Will, L. (2002). Fixed-term employees in Australia: Incidence and characteristics. Canberra, ACT, Australia: Australian Government Productivity Commission.

Watson, I. (2004). Contented casuals in inferior jobs? Reassessing causal employment in Australia. Sydney, NSW, Australia: ACIRRT, University of Sydney.

WHO Commission on Social Determinants of Health. (2003). Social Determinants of Health: The Solid Facts. Geneva, Switzerland: WHO.

WHO Commission on Social Determinants of Health. (2008). Closing the gap in a generation: Health equity through action on the social determinants of health. Geneva, Switzerland: WHO.

Wilkinson, R., \& Pickett, K. (2009). The spirit level. New York, NY: Bloomsbury Press.

Received 22 July 2011 Accepted 23 September 2011

\section{F O R T H C O M I N G}

\section{Government intervention in rural and regional Australia and beyond}

A special issue of Rural Society - Volume 21 Issue 3

ii + 110 pages - ISBN 978-1-921729-43-0 - June 2012

Editor: Troy Whitford (Charles Sturt University, Wagga Wagga NSW, Australia) http://rsj.e-contentmanagement.com/archives/vol/21/issue/3/marketing/ www.e-contentmanagement.com 
Reproduced with permission of the copyright owner. Further reproduction prohibited without permission. 